\title{
PENGARUH BAHASA IBU TERHADAP KEMAMPUAN BERBAHASA INDONESIA SISWA KELAS VII DI SMP NEGERI II BELITANG III
}

\author{
Madiah Hayati $^{{ }^{*}}$, Dedi Mardiansyah ${ }^{2}$, Chabib Kusuma Jati ${ }^{3}$ \\ Program Studi Pendidikan Bahasa dan Sastra Indonesia \\ STKIP Nurul Huda OKU Timur \\ mardiah@stkipnurulhuda.ac.id
}

\begin{abstract}
Abstrak
Penelitian ini bertujuan untuk mengetahui pengaruh bahasa ibu terhadap kemampuan berbahasa Indonesia siswa kelas VII.1 di SMP Negeri II Belitang III tahun ajaran 2021/2022. Jenis penelitian ini adalah penelitian kuantitatif. Metode yang digunakan adalah metode eksperimen kuasi, suatu tuntutan dari perkembangan ilmu pengetahuan dan teknologi agar menghasilkan pengaruh tertentu terhadap yang lain. Populasi dalam penelitian ini adalah peserta didik kelas VII.I. Sampel dalam penelitian ini menggunakan simple random sampling, pengambilan sampel dari populasi secara acak tanpa memperhatikan strata dalam populasi. Variabel bebas dalam penelitian ini adalah pengaruh bahasa ibu. Variabel terikat dalam penelitian ini adalah kemampuan berbahasa Indonesia peserta didik kelas VII.I. Teknik pengumpulan data dilakukan dengan skala dan tes kemampuan membaca. Teknik analisis data menggunakan teknik analisis deskriptif kuantitatif. Hasil penelitian ini menunjukan bahwa diperoleh nilai signifikansi (2-tailed) $0.014<0.05$ menunjukkan adanya perbedaan yang signifikan antara variabel awal dengan variabel akhir. Ini menunjukkan terdapat pengaruh yang bermakna terhadap perbedaan perlakuan yang diberikan pada masingmasing variabel. Berdasarkan nilai tersebut diketahui bahwa nilai signifikansi (2-tailed) lebih kecil, sehingga Ho ditolak dan $\mathrm{H}_{1}$ diterima. Dengan demikian, dapat disimpulkan bahwa terdapat perbedaan terhadap pengaruh bahasa ibu terhadap kemampuan berbahasa Indonesia pada siswa kelas VII.I saat pretest dan posttest.
\end{abstract}

\section{Kata kunci : Pengaruh, Bahasa Ibu, Kemampuan Berbahasa Indonesia}

\section{PENDAHULUAN}

Pendidikan merupakan kebutuhan dasar setiap manusia untuk menjamin keberlangsungan hidupnya agar lebih bermartabat. Oleh karena itu, negara memiliki kewajiban untuk memberikan pelayanan pendidikan yang bermutu kepada setiap warganya, tanpa terkecuali anak berkebutuhan khusus. Hal tersebut sesuai dengan Undang-undang Sistem Pendidikan Nasional nomor 20 Tahun 2003 Pasal 5 tentang hak dan kewajiban warga negara yang menyatakan "setiap warga negara mempunyai hak yang sama untuk memperoleh pendidikan yang bermutu". Pendidikan dipandang sebagai sarana strategis untuk mengangkat harkat dan martabat suatu bangsa, salah satunya untuk mengangkat martabat bangsa adalah pendidikan sekolah. Hal ini dikarenakan pendidikan sekolah memiliki peranan penting sebagai institusi yang mengelola dan mengembangkan berbagai bidang keilmuan. Di samping itu pendidikan yang berkualitas merupakan aset bangsa untuk menciptakan keunggulan dan daya saing bangsa.

Sekolah menengah pertama (SMP) Negeri II Belitang III merupakan salah satu sekolah yang telah melahirkan lulusan dari tahun 80-an sampai dengan sekarang. Sekolah yang berdiri di Desa Trikarya Kecamatan Belitang III ini merupakan sekolah favorit masyarakat sekitar. Tidak bisa dipungkiri bahwasanya untuk menghasilkan siswa yang berkompetensi dibutuhkan seorang guru yang profesional. Namun, masalah yang dihadapi seorang guru untuk meningkatkan kemampuan Berbahasa Indonesia terkendala dengan adanya bahasa ibu atau bahasa pertama yang cenderung menghambat kemampuan berbahsa Indonesia pada siswa kelas VII. Masyarakat di sana umumnya memiliki pergaulan yang sangat luas bahkan mereka setiap hari berinteraksi dengan beberapa suku seperti Jawa, Sunda, Komering, hingga Lampung, sehingga besar sekali kemungkinan masyarakat memiliki kemampuan dwibahasa (bilingualisme) yang terdapat hampir di seluruh desa, dalam semua kelas sosial, dan semua kelompok umur.

Penelitian ini beranjak dari fenomena di mana anak-anak Karya Makmur dan Trikarya yang telah bersekolah di SMP Negeri II Belitang III dan telah menjadi dwibahasa sejak dari usia muda, yaitu usia 5-7 

bahasa ke dua selama masa kritis pemerolehan bahasa pertama, yaitu sebelum usia 6-7 tahun. Mereka kemungkinan besar juga sudah menjadi pengguna bahasa yang kompeten karena anak pada usia antara 2 sampai 6 tahun memperoleh atau belajar bahasa dengan sangat cepat.

Kemampuan berbahasa adalah kemampuan istimewa yang hanya dimiliki oleh spesies manusia setelah bahasa ibu diperoleh maka pada usia tertentu anak memperoleh bahasa lain atau bahasa kedua yang ia kenal sebagai khazanah pengetahuan yang baru. Bahasa merupakan alat komunikasi yang diperoleh manusia sejak lahir. Pada awal bayi dilahirkan belum memiliki kemampuan dalam berbicara dengan orang lain. Penguasaan sebuah bahasa oleh seorang anak dimulai dengan perolehan bahasa pertama yang sering kali disebut bahasa ibu.

Dengan semakin bertambahnya usia anak pemerolehan bahasa juga semakin meningkat. Faktor pendidikan orang tua juga membawa dampak terhadap pemerolehan bahasa anak. Orang tua yang tingkat pendidikanya lebih baik akan memberikan bahasa yang lebih akurat untuk anaknya, sehingga terekam ke memori anak. Demikian juga pada anak jika di dalam faktor lingkungan anak bisa mengendalikan emosi bahasanya maka yang akan terjadi tidak akan mendapatkan kesulitan dalam berbahasa Indonesia dalam situasi resmi seperti di sekolah-sekolah dan tempat resmi lainya, apakah mereka cenderung menggunakan bahasa ibu untuk melakukan komunikasi dan interaksi antara sesama teman atau apakah ada pengaruh bahasa ibu terhadap kemampuan berbahasa Indonesia yang selama ini terjadi khususnya di lingkungan sekolah SMP N II Belitang III. Merujuk dari permasalahan yang ada maka tujuan penelitian ini secara umum untuk mengetahui bagaimana pengaruh bahasa ibu terhadap kemampuan berbahasa Indonesia siswa kelas VII.1 di SMP Negeri II Belitang III.

Terdapat beberapa faktor yang dapat memengaruhi kegiatan proses pembelajaran, di antaranya faktor guru, faktor siswa, faktor sarana, alat dan media yang tersedia, serta faktor lingkungan (Sanjaya, 2013: 56). Chomsky berpendapat dalam pemerolehan bahasa didasarkan pada beberapa asumsi. Pertama, perilaku berbahasa adalah sesuatu yang diturunkan (genetik), setiap bahasa memiliki pola perkembangan yang sama (merupakan sesuatu yang universal), dan lingkungan memiliki peran kecil dalam proses pematangan bahasa. Kedua, bahasa dapat dikuasai dalam waktu yang relatif singkat. Ketiga, lingkungan bahasa anak tidak dapat menyediakan data yang cukup bagi penguasaan tata bahasa yang rumit dari orang dewasa (Ghazali, 2010: 5). Dapat disimpulkan bahasa merupakan sesuatu yang kompleks dan rumit sehingga mustahil dapat dikuasai dalam waktu yang singkat.

\section{METODE PENELITIAN}

Jenis penelitian yang digunakan dalam penelitian ini adalah jenis penelitian kuantitatif. Jenis penelitian kuantitatif adalah jenis penelitian yang berlandaskan pada filsafat positivisme, digunakan untuk meneliti pada populasi atau sampel tertentu (Sugiyono, 2012: 8). Penelitian ini termasuk eksperimen kuasi (quasi experiment) sebagai eksperimen yang memiliki perlakuan dan pengukuran dampak. Populasi dalam penelitian ini adalah seluruh siswa kelas VII SMP II Belitang III. Sampel dalam penelitian ini menggunakan simple random sampling. Dalam pengambilan sampel kelas yang terpilih yaitu kelas VII.I. Variabel merupakan objek penelitian atau sesuatu yang akan menjadi pusat perhatian dalam penelitian (Arikunto, 2014: 161).

Variabel dibagi menjadi dua yaitu variabel bebas $(X)$ dan variabel terikat $(Y)$. Sugiyono (2012: 38) mengatakan bahwa variabel penelitian adalah suatu atribut atau sifat atau nilai dari orang, obyek atau kegiatan yang mempunyai variasi tertentu yang ditetapkan oleh peneliti untuk dipelajari dan kemudian ditarik kesimpulannya. Teknik pengumpulan data dengan menggunakan tes. Menurut Aedi (2010: 3) "tes dapat berupa serentetan pertanyaan, lembar kerja, atau sejenisnya yang dapat digunakan untuk mengukur pengetahuan." Tes yang dibuat berupa soal yang dilaksanakan sebelum dan setelah treatment diberikan.

Validitas yang digunakan dalam penelitian ini adalah validitas isi (Content Validity). Validitas isi adalah derajad di mana sebuah tes mengukur cakupan subtansi yang ingin diukur. Untuk instrumen yang berbentuk tes, pengujian validitas dapat dilakukan dengan membandingkan antara isi instrumen dengan materi pelajaran yang telah diajarkan (Sugiyono, 2012: 125). Reliabilitas penelitian ini adalah reliabilitas test-retest (stability). Test-retest adalah instrumen penelitian yang reliabilitasnya diuji dengan cara mencobakan instrumen beberapa kali pada responden (Sugiyono, 2018: 130). Mengukur reliabilitas tes pemahaman menggunakan perhitungan SPSS versi 25 dengan bantuan komputer. Teknik yang digunakan untuk menganalisis data adalah dengan teknik analisis data deskriptif Madiah Hayati, Dedi Mardiansyah, Chabib Kusuma Jati 
PENGARUH BAHASA IBU TERHADAP KEMAMPUAN BERBAHASA .... $\mid 11$ kuantitatif. Teknik analisis ini merupakan prosedur statistik untuk menguji generalisasi hasil penelitian yang didasarkan atas satu variabel. Uji ini tergantung pada jenis data (Sugiyono, 2012: 147). Langkahlangkah dalam mengolah data adalah 1) membuat daftar skor pretest \& posttest, 2) membuat distribusi frekuensi dari skor, 3) menghitung nilai kemampuan siswa, 4) uji normalitas dan homogenitas, 5) uji-t ( $t$ test).

\section{HASIL DAN PEMBAHASAN}

Hasil

Berdasarkan hasil penghitungan secara kuantitatif diketahui bahwa kemampuan bebahasa yang dimiliki siswa pada kategori baik. Hasil analisis data menunjukkan nilai rata-rata pretest kemampuan berbahasa adalah 3,33, dan hasil analisis data menunjukkan nilai rata-rata posttest kemampuan berbahasa adalah 3,48. Skor 3,48 tersebut dikonversikan ke dalam skala lima, terletak pada interval kategori baik yaitu $3,33<$ skor $\leq 3,66$. Hasil tersebut sesuai dengan hipotesis yang menyatakan kemampuan berbahasa siswa kelas VII.I berkategori baik dan terdapat perbedaan yang signifikan.

\section{Pembahasan}

Penelitian ini dilaksanakan untuk mendeskripsikan kemampuan berbahasa. Data yang diperoleh dalam penelitian ini berupa data kuantitatif yaitu berupa data skor yang diperoleh dengan cara memberi tes kemampuan berbahasa kepada siswa. Selanjutnya diharapkan terdapat perbedaan yang signifikan sebelum dan sesudah penelitian. Peneliti terlebih dahulu mengadakan tes kemampuan awal (pretest).

Tabel 2

Data Presentase Nilai Pretest dan Postest

\begin{tabular}{|c|c|c|c|c|c|c|c|c|}
\hline & Interval & \multicolumn{3}{|c|}{ Nilai Ubahan Skala Lima } & \multicolumn{2}{|c|}{ Pretest } & \multicolumn{2}{|c|}{ Posttest } \\
\cline { 3 - 10 } N & $\begin{array}{c}\text { Presentase } \\
\text { Tingkat } \\
\text { Penguasaan }\end{array}$ & $\mathbf{0 - 4}$ & E-A & Keterangan & F & (\%) & F & (\%) \\
\hline 1 & $85 \%-100 \%$ & 4 & $\mathrm{~A}$ & Sempurna & 1 & 3.125 & 4 & 12.5 \\
\hline 2 & $75 \%-84 \%$ & 3 & $\mathrm{~B}$ & Baik Sekali & 17 & 53.125 & 25 & 78.125 \\
\hline 3 & $60 \%-74 \%$ & 2 & $\mathrm{C}$ & Baik Sekali & 7 & 21.875 & 3 & 9.375 \\
\hline 4 & $40 \%-59 \%$ & 1 & $\mathrm{D}$ & Cukup & 5 & 15.625 & 1 & 3.125 \\
\hline 5 & $0 \%-39 \%$ & 0 & $\mathrm{E}$ & Sedang & 2 & 6.25 & 0 & 0 \\
\hline \multicolumn{3}{|c}{ Jumlah } & 32 & 100 & 32 & 100 \\
\hline
\end{tabular}

Perbedaan kemampuan berbahasa dapat diketahui dari banyaknya siswa yang tuntas dalam pembelajaran kemampuan berbahasa. Dengan demikian terdapat pengaruh bahasa ibu terhadap kemampuan berbahasa Indonesia. Hal tersebut membuktikan bahwa terdapat perbedaan antara sebelum dan sesudah penelitian.

Tabel 3

Data Jumlah Siswa yang Tuntas dan Tidak Tuntas

\begin{tabular}{|l|l|c|c|c|}
\hline \multirow{2}{*}{ No } & \multicolumn{1}{|c|}{ Tes } & Siswa & \multicolumn{2}{|c|}{ Jumlah Siswa } \\
\cline { 4 - 5 } & \multicolumn{1}{|c|}{$\begin{array}{l}\text { Tes Kemampuan Awal } \\
\text { (pretest) }\end{array}$} & 32 & Tuntas & Tidak Tuntas \\
\hline 2 & $\begin{array}{l}\text { Tes Kemampuan Akhir } \\
\text { (posttest) }\end{array}$ & 32 & 31 & 1 \\
\hline
\end{tabular}


Dalam pedoman penilaian yang telah ditetapkan oleh peneliti, terdapat empat aspek yang dinilai pada hasil tes siswa, yaitu aspek kemampuan membaca, kemampuan berbicara, kemampuan menyimak, dan menulis. Setiap aspek yang dinilai dengan menggunakan skala 1-5. Skala 1 mewakili skor terendah dan skala 5 mewakili skor tertinggi. Skor yang diperoleh siswa untuk masing-masing kategori dijumlah, kemudian dibagi lima.

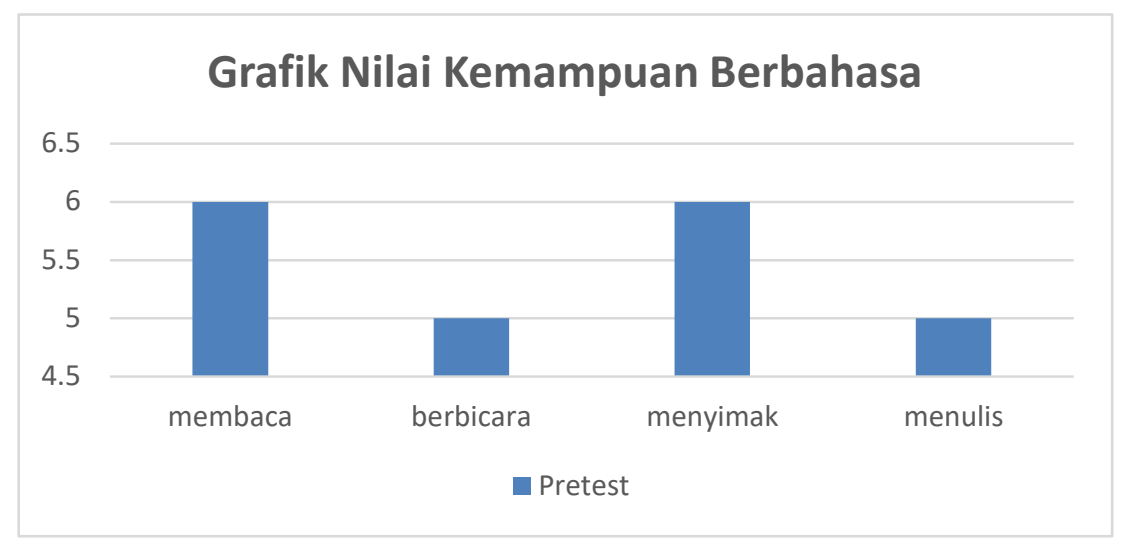

\section{Grafik 1 \\ Nilai Pretest Kemampuan Berbahasa}

Peneliti membagi kelas menjadi lima kelompok. Selanjutnya, siswa diberikan beberapa materi kemampuan berbahasa. Dalam diskusi kelompok, siswa melakukan kegiatan mengamati, menanya, menalar, mencoba, dan mengomunikasikan. Setelah siswa selesai menganalisis dalam kelompok, selanjutnya siswa mengomunikasikan dengan mempresentasikan hasil diskusi kelompok dan kelompok lain saling menanggapi. Peneliti memberi penguatan dan refleksi setelah semua kelompok selesai melakukan presentasi.

Setelah semua kegiatan sudah dilaksanakan, peneliti melakukan tes kemampuan akhir atau posttest kemampuan berbahasa kelas VII.I. Hasil tes kemampuan kedua yang dilakukan peneliti dapat dilihat pada tabel dan grafik berikut.

Tabel 4

Data Skor Posttest Siswa Kelas VII.I

\begin{tabular}{|c|c|c|c|c|c|}
\hline No & $\begin{array}{c}\text { Kode } \\
\text { Siswa }\end{array}$ & Nilai & KKM & $\begin{array}{c}\text { Nilai } \\
\text { Konv. }\end{array}$ & Ket \\
\hline 1 & S_1 & 3.2 & 72 & 80 & tuntas \\
\hline 2 & S_2 & 3.6 & 72 & 90 & tuntas \\
\hline 3 & S_3 & 3 & 72 & 75 & tuntas \\
\hline 4 & S_4 & 4 & 72 & 100 & tuntas \\
\hline 5 & S_5 & 3 & 72 & 75 & tuntas \\
\hline 6 & S_6 & 3.8 & 72 & 95 & tuntas \\
\hline 7 & S_7 & 3.5 & 72 & 87.5 & tuntas \\
\hline 8 & S_8 & 3.5 & 72 & 87.5 & tuntas \\
\hline 9 & S_9 & 3.6 & 72 & 90 & tuntas \\
\hline 10 & S_10 & 3.5 & 72 & 87.5 & tuntas \\
\hline 11 & S_11 & 3.6 & 72 & 90 & tuntas \\
\hline 12 & S_12 & 3.8 & 72 & 95 & tuntas \\
\hline 13 & S_13 & 3.6 & 72 & 90 & tuntas \\
\hline 14 & S_14 & 2.6 & 72 & 65 & tidak tuntas \\
\hline 15 & S_15 & 4 & 72 & 100 & tuntas \\
\hline 16 & S_16 & 3.7 & 72 & 92.5 & tuntas \\
\hline 17 & S_17 & 3.6 & 72 & 90 & tuntas \\
\hline
\end{tabular}


PENGARUH BAHASA IBU TERHADAP KEMAMPUAN BERBAHASA .... $\mid 13$

\begin{tabular}{|l|c|c|c|c|c|}
18 & S_18 & 3.8 & 72 & 95 & tuntas \\
\hline 19 & S_19 & 3.6 & 72 & 90 & tuntas \\
\hline 20 & S_20 & 3.2 & 72 & 80 & tuntas \\
\hline 21 & S_21 & 4 & 72 & 100 & tuntas \\
\hline 22 & S_22 & 3.4 & 72 & 85 & tuntas \\
\hline 23 & S_23 & 3.8 & 72 & 95 & tuntas \\
\hline 24 & S_24 & 3.4 & 72 & 85 & tuntas \\
\hline 25 & S_25 & 3 & 72 & 75 & tuntas \\
\hline 26 & S_26 & 4 & 72 & 100 & tuntas \\
\hline 27 & S_27 & 3.4 & 72 & 85 & tuntas \\
\hline 28 & S_28 & 3.8 & 72 & 95 & tuntas \\
\hline 29 & S_29 & 3.7 & 72 & 92.5 & tuntas \\
\hline 30 & S_30 & 3.6 & 72 & 90 & tuntas \\
\hline 31 & S_31 & 2.9 & 72 & 72.5 & tuntas \\
\hline 32 & S_32 & 2.4 & 72 & 60 & tidak tuntas \\
\hline
\end{tabular}

Dalam pedoman penilaian yang telah ditetapkan, terdapat empat aspek yang dinilai pada hasil tes siswa, yaitu aspek kemampuan membaca pemahaman, berbicara, menyimak, dan menulis. Setiap aspek yang dinilai dengan menggunakan skala 1-5. Skala 1 mewakili skor terendah dan skala 5 mewakili skor tertinggi. Skor yang diperoleh siswa untuk masing-masing kategori dijumlah, kemudian dibagi lima.

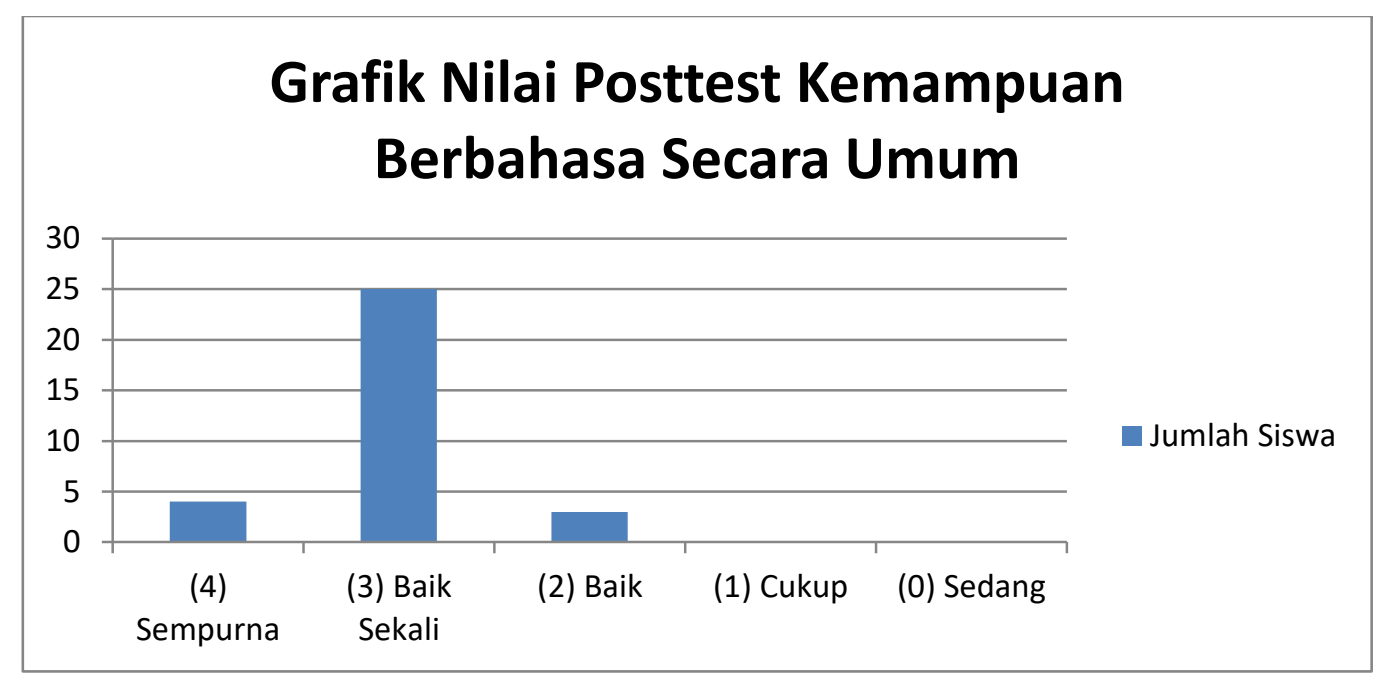

Grafik 2

Nilai Posttest Kemampuan Berbahasa Secara Umum

Berdasarkan data tersebut untuk Pretest dapat disimpulkan bahwa, untuk nilai sempurna dengan skor 4 diperoleh 4 orang, sedangkan untuk nilai baik sekali dengan skor 3 diperoleh 25 orang, dan untuk nilai baik dengan skor 2 diperoleh 3 orang.

Analisis data dilakukan dengan menghitung rata-rata (mean), uji normalitas, uji homogenitas, dan melakukan uji-t. Jumlah siswa yang terlibat adalah 32 orang. Tes dilakukan untuk mengetahui kemampuan awal siswa sebelum diberikan perlakuan (treatment). Dari pretest diperoleh skor tertinggi 4 dan skor terendah 2,5.

Tes kemampuan akhir Jumlah siswa yang terlibat adalah 32 orang. Tes dilakukan untuk mengetahui kemampuan siswa setelah diberikan perlakuan (treatment). Dari hasil nilai diperoleh skor tertinggi 4,0 dan skor terendah 2,4. Hasil kemampuan berbahasa ditabulasikan ke dalam tabel. Tabel digunakan untuk menggambarkan data-data sebagai persiapan menghitung kemampuan berbahasa. 
Data secara lengkap dimuat dalam tabel di bawah ini.

\begin{tabular}{|c|c|c|c|c|c|c|c|c|c|c|c|c|c|}
\hline \multicolumn{14}{|c|}{ Descriptive Statistics } \\
\hline & $\mathrm{N}$ & $\begin{array}{c}\text { Ran } \\
\text { ge }\end{array}$ & $\begin{array}{c}\mathrm{Mi} \\
\mathrm{n}\end{array}$ & $\begin{array}{c}\text { Ma } \\
x\end{array}$ & Sum & \multicolumn{2}{|c|}{ Mean } & $\begin{array}{l}\text { Std. } \\
\text { Devi } \\
\text { ation }\end{array}$ & $\begin{array}{c}\text { Vari } \\
\text { anc } \\
\text { e }\end{array}$ & Skew & less & \multicolumn{2}{|c|}{ Kurtosis } \\
\hline & $\begin{array}{c}\text { Sta } \\
\text { tisti } \\
\text { C }\end{array}$ & $\begin{array}{l}\text { Stati } \\
\text { stic }\end{array}$ & $\begin{array}{c}\text { Sta } \\
\text { tisti } \\
\text { C }\end{array}$ & $\begin{array}{c}\text { Sta } \\
\text { tisti } \\
\text { C }\end{array}$ & $\begin{array}{c}\text { Statist } \\
\text { ic }\end{array}$ & $\begin{array}{l}\text { Stati } \\
\text { stic }\end{array}$ & $\begin{array}{c}\text { Std. } \\
\text { Erro } \\
r\end{array}$ & $\begin{array}{l}\text { Stati } \\
\text { stic }\end{array}$ & $\begin{array}{l}\text { Stati } \\
\text { stic }\end{array}$ & $\begin{array}{c}\text { Statist } \\
\text { ic }\end{array}$ & $\begin{array}{c}\text { Std. } \\
\text { Erro } \\
r\end{array}$ & $\begin{array}{c}\text { Sta } \\
\text { tisti } \\
\text { C }\end{array}$ & $\begin{array}{l}\text { Std. } \\
\text { Error }\end{array}$ \\
\hline Posttest & 32 & 1.60 & $\begin{array}{r}2.4 \\
0\end{array}$ & $\begin{array}{r}4.0 \\
0\end{array}$ & $\begin{array}{r}111.6 \\
0\end{array}$ & $\begin{array}{r}3.48 \\
75\end{array}$ & $\begin{array}{r}.070 \\
53\end{array}$ & $\begin{array}{r}.398 \\
99\end{array}$ & .159 & -1.010 & .414 & $\begin{array}{r}.78 \\
1\end{array}$ & .809 \\
\hline $\begin{array}{l}\text { Valid N } \\
\text { (listwise } \\
\text { ) }\end{array}$ & 32 & & & & & & & & & & & & \\
\hline
\end{tabular}

Jadi, rata-rata pretest kemampuan berbahasa adalah 3,33 dan nilai rata-rata posttest kemampuan berbahasa adalah 3,48 . Terdapat perbedaan nilai rata-rata yang signifikan pada pretest dan posttest. Uji normalitas digunakan untuk menguji normal tidaknya data yang akan dianalisis. Data berdistribusi normal digunakan sebagai syarat untuk melakukan pengujian selanjutnya. Sedangkan uji homogenitas dilakukan untuk mengetahui bahwa dua atau lebih kelompok data sampel berasal dari populasi yang meiliki varians sama (homogen). Pengujian normalitas dan homogenitas menggunakan progam SPSS versi 25 dengan bantuan komputer.

\begin{tabular}{|c|c|c|}
\hline \multicolumn{3}{|c|}{ One-Sample Kolmogorov-Smirnov Test } \\
\hline & & $\begin{array}{c}\text { PRETEST \& } \\
\text { POSTEST }\end{array}$ \\
\hline \multicolumn{2}{|l|}{$\mathrm{N}$} & 32 \\
\hline \multirow[t]{2}{*}{ Normal Parameters ${ }^{\mathrm{a}, \mathrm{b}}$} & Mean & .0000000 \\
\hline & Std. Deviation & 7.06541001 \\
\hline \multirow[t]{3}{*}{ Most Extreme Differences } & Absolute & .131 \\
\hline & Positive & .131 \\
\hline & Negative & -.126 \\
\hline \multicolumn{2}{|l|}{ Test Statistic } & .131 \\
\hline Asymp. Sig. (2-tailed) & & $.180^{\mathrm{C}}$ \\
\hline \multicolumn{3}{|c|}{ a. Test distribution is Normal. } \\
\hline \multicolumn{3}{|c|}{ b. Calculated from data. } \\
\hline \multicolumn{3}{|c|}{ c. Lilliefors Significance Correction. } \\
\hline
\end{tabular}

Berdasarkan hasil uji normalitas diketahui nilai signifikansi $0,180>0,05$. Maka dapat disimpulkan bahwa nilai residual berdistribusikan normal.

\begin{tabular}{|c|c|c|c|c|c|}
\hline \multicolumn{6}{|c|}{ Test of Homogeneity of Variances } \\
\hline & & $\begin{array}{l}\text { Levene } \\
\text { Statistic }\end{array}$ & df1 & df2 & Sig. \\
\hline \multirow[t]{4}{*}{ Hasil Belajar } & Based on Mean & 2.081 & 1 & 62 & .154 \\
\hline & Based on Median & 1.244 & 1 & 62 & .269 \\
\hline & $\begin{array}{l}\text { Based on Median and } \\
\text { with adjusted df }\end{array}$ & 1.244 & 1 & 61.964 & .269 \\
\hline & Based on trimmed mean & 2.138 & 1 & 62 & .149 \\
\hline
\end{tabular}




\begin{tabular}{|l|r|r|r|r|c|}
\hline \multicolumn{7}{|c|}{ ANOVA } \\
\hline & $\begin{array}{c}\text { Sum of } \\
\text { Squares }\end{array}$ & df & Mean Square & F & Sig. \\
\hline Between Groups & 225.000 & 1 & 225.000 & 2.027 & .160 \\
\hline Within Groups & 6881.250 & 62 & 110.988 & & \\
\hline Total & 7106.250 & 63 & & & \\
\hline
\end{tabular}

Berdasarkan hasil uji homogenitas diketahui nilai signifikansi 0,154>0,05. Maka dapat disimpulkan bahwa distribusi data homogen. Perhitungan uji-t menggunakan aplikasi SPSS versi 25 dengan bantuan komputer, untuk membuktikan apakah ada perbedaan yang signifikan bahasa ibu terhadap kemampuan berbahasa saat pretest dan posttes, peneliti akan melakukan analisis terhadap hasil perhitungan dengan SPSS versi 25 sebagai berikut.

\begin{tabular}{|c|c|c|}
\hline Kode Siswa & Nilai Pretest & Nilai Posttest \\
\hline S_1 & 72.5 & 80 \\
\hline S_2 & 92.5 & 90 \\
\hline S_3 & 72.5 & 75 \\
\hline S_4 & 97.5 & 100 \\
\hline S_5 & 67.5 & 75 \\
\hline S_6 & 95 & 95 \\
\hline S_7 & 92.5 & 87.5 \\
\hline S_8 & 92.5 & 87.5 \\
\hline S_9 & 62.5 & 90 \\
\hline S_10 & 87.5 & 87.5 \\
\hline S_11 & 92.5 & 90 \\
\hline S_12 & 95 & 95 \\
\hline S_13 & 75 & 90 \\
\hline S_14 & 65 & 65 \\
\hline S_15 & 100 & 100 \\
\hline S_16 & 70 & 92.5 \\
\hline S_17 & 90 & 90 \\
\hline S_18 & 90 & 95 \\
\hline S_19 & 90 & 90 \\
\hline S_20 & 72.5 & 80 \\
\hline S_21 & 92.5 & 100 \\
\hline S_22 & 87.5 & 85 \\
\hline S_23 & 85 & 95 \\
\hline S_24 & 77.5 & 85 \\
\hline S_25 & 75 & 75 \\
\hline S_26 & 90 & 100 \\
\hline S_27 & 85 & 85 \\
\hline S_28 & 95 & 95 \\
\hline S_29 & 82.5 & 92.5 \\
\hline S_30 & 90 & 90 \\
\hline S_31 & 62.5 & 72.5 \\
\hline S_32 & 75 & 60 \\
\hline & & \\
\hline & & \\
\hline & & \\
\hline
\end{tabular}

$H_{o} \quad$ : Tidak ada pengaruh bahasa ibu terhadap kemampuan berbahasa Indonesia peserta didik kelas VII.I SMP Negeri II Belitang III saat prestest dan posttest

$H_{1} \quad$ : Ada pengaruh Bahasa ibu terhadap kemampuan berbahasa Indonesia pada peserta didik kelas VII.I SMP Negeri II Belitang III saat pretest dan posttest 


\begin{tabular}{|l|l|l|r|r|c|}
\hline \multicolumn{7}{|c|}{ Paired Samples Statistics } \\
\hline \multirow{2}{|l|}{} & Mean & $\mathrm{N}$ & Std. Deviation & $\begin{array}{c}\text { Std. Error } \\
\text { Mean }\end{array}$ \\
\hline Pair 1 & pretest & 83.4375 & 32 & 11.06706 & 1.95640 \\
\cline { 2 - 6 } & posttest & 87.1875 & 32 & 9.97477 & 1.76331 \\
\hline
\end{tabular}

\begin{tabular}{|l|l|r|r|r|}
\hline \multicolumn{6}{|c|}{ Paired Samples Correlations } \\
\hline \multicolumn{7}{|c|}{} & $\mathrm{N}$ & Correlation & \multicolumn{1}{c|}{ Sig. } \\
\hline Pair 1 & pretest \& posttest & 32 & .706 & .000 \\
& & & & \\
\hline
\end{tabular}

\begin{tabular}{|c|c|c|c|c|c|c|c|c|c|}
\hline \multicolumn{10}{|c|}{ Paired Samples Test } \\
\hline & & \multicolumn{5}{|c|}{ Paired Differences } & \multirow[b]{3}{*}{$\mathrm{t}$} & \multirow[b]{3}{*}{ df } & \\
\hline & & \multirow[b]{2}{*}{ Mean } & \multirow{2}{*}{$\begin{array}{c}\text { Std. } \\
\text { Deviatio } \\
n\end{array}$} & \multirow{2}{*}{$\begin{array}{l}\text { Std. } \\
\text { Error } \\
\text { Mean }\end{array}$} & \multicolumn{2}{|c|}{$\begin{array}{l}95 \% \text { Confidence } \\
\text { Interval of the } \\
\text { Difference }\end{array}$} & & & \multirow{2}{*}{$\begin{array}{l}\text { Sig. (2- } \\
\text { tailed) }\end{array}$} \\
\hline & & & & & Lower & Upper & & & \\
\hline Pair 1 & $\begin{array}{l}\text { pretest } \\
- \\
\text { posttest }\end{array}$ & -3.75000 & 8.13198 & $\begin{array}{r}1.4375 \\
4\end{array}$ & $\begin{array}{r}- \\
6.68189\end{array}$ & -.81811 & -2.609 & 31 & .014 \\
\hline
\end{tabular}

Dari hasil penghitungan tersebut, diperoleh nilai signifikansi (2-tailed) $0.014<0.05$ menunjukkan adanya perbedaan yang signifikan antara variabel awal dengan variabel akhir. Ini menunjukkan terdapat pengaruh yang bermakna terhadap perbedaan perlakuan yang diberikan pada masing-masing variabel. Berdasarkan nilai tersebut diketahui bahwa nilai signifikansi (2-tailed) lebih kecil, sehingga $\mathrm{Ho}$ ditolak dan $\mathrm{H}_{1}$ diterima. Dengan demikian, dapat disimpulkan bahwa terdapat perbedaan pengaruh bahasa ibu terhadap kemampuan berbahasa pada siswa kelas VII.I SMP Negeri II Belitang III saat pretest dan posttest. Pengaruh bahasa ibu terhadap kemampuan berbahasa siswa kelas VII.I SMP Negeri II Belitang III saat sebelum penelitian dan setelah penelitian memiliki perbedaan yang signifikan.

\section{PENUTUP}

Berdasarkan pembahasan pengaruh bahasa ibu terhadap kemampuan berbahasa Indonesia siswa kelas VII.I SMP Negeri II Belitang III, maka dapat disimpulkan bahwa kemampuan berbahasa siswa kelas VII.I berkategori baik dan terdapat perbedaan yang signifikan. Dari hasil penghitungan, diperoleh nilai signifikansi (2-tailed) $0.014<0.05$ menunjukkan adanya perbedaan yang signifikan antara variabel awal dengan variabel akhir. Ini menunjukkan terdapat pengaruh yang bermakna terhadap perbedaan perlakuan yang diberikan pada variabel. Berdasarkan nilai tersebut diketahui bahwa nilai signifikansi (2-tailed) lebih kecil, sehingga $\mathrm{Ho}$ ditolak dan $\mathrm{H}_{1}$ diterima. Dengan demikian, dapat disimpulkan bahwa terdapat perbedaan pengaruh bahasa ibu terhadap kemampuan berbahasa Indonesia pada siswa kelas VII.I saat pretest dan posttest.

UCAPAN TERIMAKASIH

Ucapan terima kasih ditujukan kepada ketua STKIP Nurul Huda dan TIM peneliti.

\section{DAFTAR PUSTAKA}

Aedi, Nur. 2010. Pengolahan dan Analisis Data Hasil Penelitian. Bandung: Universitas Pendidikan Indonesia.

Arikunto, Suharsimi. 2014. Prosedur Penelitian (Suatu Pendekatan Praktik). Jakarta: PT. Rineka Cipta. 
PENGARUH BAHASA IBU TERHADAP KEMAMPUAN BERBAHASA .... $\mid 17$ Ghazali, A. Syukur. 2010. Pembelajaran Keterampilan Berbahasa. Bandung: Refika Aditama.

Nurgiatoro, Burhan. 2010. Penilaian Pembelajaran Bahasa Berbasis Kompetensi. Yogyakarta: BPFEYogyakarta.

Sanjaya, Wina. 2013. Strategi Pembelajaran. Jakarta: Kencana.

Sugiyono. 2012. Metode Penelitian Kuantitatif, Kualitatif, dan R\&D. Bandung: ALFABETA. 